\title{
STUDI KOMPARASI MODEL PEMBELAJARAN INKUIRI TERBIMBING DAN SIKLUS BELAJAR 5E DITINJAU DARI KEMAMPUAN MATEMATIKA TERHADAP HASIL BELAJAR SISWA PADA MATERI KELARUTAN DAN HASIL KALI KELARUTAN KELAS XI SMA NEGERI 1 BOYOLALI TAHUN PELAJARAN 2016/2017
}

\author{
Febi Nur Fitriani ${ }^{*}$, Agung Nugroho C.S, Mohammad Masykuri \\ Program Studi Pendidikan Kimia, FKIP, Universitas Sebelas Maret, Surakarta, Indonesia \\ *Keperluan Korespondensi, telp: 085726329399, email: febipebhe@gmail.com
}

\begin{abstract}
ABSTRAK
Penelitian ini bertujuan untuk mengetahui pengaruh penggunaan model pembelajaran inkuiri terbimbing dan siklus belajar 5E (SB 5E) terhadap hasil belajar siswa, pengaruh kemampuan matematika terhadap hasil belajar siswa dan interaksi keduanya terhadap hasil belajar siswa pada materi kelarutan dan hasil kali kelarutan. Penelitian ini menggunakan metode eksperimen desain faktorial $2 \times 2$ dengan teknik pengambilan sampel cluster random sampling. Pengumpulan data penelitian menggunakan instrumen tes untuk kemampuan matematika dan aspek pengetahuan, angket untuk aspek sikap serta observasi untuk aspek sikap dan keterampilan. Analisis data aspek pengetahuan dan keterampilan menggunakan analisis variansi (anava) dua jalan, sedangkan analisis data prestasi aspek sikap menggunakan uji statistik non parametrik Kruskal Wallis $H$. Kesimpulan yang diperoleh berdasarkan hasil penelitian yaitu: (1) terdapat pengaruh model pembelajaran inkuiri terbimbing dan SB 5E terhadap prestasi belajar siswa aspek pengetahuan, tetapi tidak untuk aspek sikap dan keterampilan (2) terdapat pengaruh kemampuan matematika terhadap prestasi belajar aspek pengetahuan, sedangkan pada aspek sikap dan keterampilan tidak ada pengaruh kemampuan matematika terhadap prestasi belajar siswa (3) Tidak ada interaksi antara model pembelajaran inkuiri terbimbing dan SB 5E dengan kemampuan matematika terhadap prestasi belajar aspek pengetahuan, sikap maupun keterampilan.
\end{abstract}

Kata Kunci: inkuiri terbimbing, siklus belajar 5E, kemampuan matematika, hasil belajar, kelarutan dan hasil kali kelarutan

\section{PENDAHULUAN}

Kualitas pendidikan Indonesia dilihat dari kemampuan membaca, matematika dan sains mendapatkan peringkat 62 dari 72 negara menurut data Programme for International Student Assessment (PISA) tahun 2015 [1]. Pemerintah Indonesia sebenarnya tidak tinggal diam mengenai kualitas pendidikan tersebut. Berbagai upaya untuk memperbaiki kualitas pendidikan telah dilakukan. Upaya tersebut di antaranya dikeluarkan Undang-Undang Sistem Pendidikan Nasional tahun 2003 , Peraturan Pemerintah (PP) No. 19 tahun 2005 tentang Standar Nasional
Pendidikan (SNP) yang ditata kembali dalam PP No. 32 tahun 2013 serta berbagai peraturan kementerian pendidikan yang mendukung perbaikan sistem pendidikan. Salah satu komponen utama pendidikan yang mengalami perubahan paling baru tertuang dalam PP No. 32 tahun 2013 adalah perubahan kurikulum yang sebelumnya berupa Kurikulum Tingkat Satuan Pendidikan menjadi kurikulum 2013. Kurikulum 2013 ini diberlakukan mulai tahun pelajaran 2013/2014 dan dilaksanakan secara bertahap.

Menurut Peraturan Menteri Pendidikan dan Kebudayaan (Permen- 
dikbud) Nomor 70 tahun 2013, kurikulum 2013 mengembangkan pola pembelajaran berpusat pada peserta didik, interaktif, aktif, berbasis alat multimedia dan kritis. Implementasi kurikulum 2013 dalam pendidikan sekolah menengah lebih menekankan pada pendekatan ilmiah (scientific). Permendikbud Nomor 22 tahun 2016 menambahkan bahwa untuk memperkuat pendekatan ilmiah (scientific) perlu diterapkan pembelajaran berbasis penyingkapan atau penelitian (discovery or inquiry learning) dan berbasis masalah (problem solving or problem based learning). Implementasi kurikulum 2013 ini tidaklah mudah dilihat dari masih banyak sekolah yang menerapkan kurikulum 2013 belum sepenuhnya berjalan sebagaimana mestinya. Salah satu instansi pendidikan yang menerapkan kurikulum 2013 adalah SMA Negeri 1 Boyolali. SMA N 1 Boyolali termasuk dari sekian sekolah yang sudah menerapkan kurikulum 2013 sejak tahun pelajaran 2013/2014 sampai dengan sekarang.

Berdasarkan hasil wawancara dengan guru kimia pada tanggal 17 April 2017 di SMA ini diketahui bahwa pembelajaran kimia di sekolah belum sepenuhnya menerapkan pembelajaran berdasarkan kurikulum 2013. Proses pembelajaran yang terjadi belum sepenuhnya melibatkan siswa secara aktif seperti yang diinginkan kurikulum 2013. Berdasarkan hasil observasi kegiatan pembelajaran di kelas, siswa cenderung pasif saat diterapkan pembelajaran yang tidak melibatkan siswa dalam prosesnya walaupun masih ada beberapa siswa yang aktif bertanya. Siswa cenderung lebih aktif dan bersemangat saat dilaksanakan kegiatan praktikum yang melibatkan siswa dalam pembelajaran. Kondisi ini menyebabkan perlu adanya pemakaian model lain untuk menumbuhkan keinginan belajar siswa dan lebih melibatkan siswa dalam pembelajaran. Hal ini didukung pendapat bahwa pembelajaran yang tidak banyak melibatkan siswa akan mematikan kreativitas siswa dan menghilangkan kesempatan siswa untuk memperlihatkan potensinya [2].
Menurut guru kimia kelas XI SMA $\mathrm{N} 1$ Boyolali, materi kelarutan dan hasil kali kelarutan merupakan salah satu materi kimia yang dirasa sulit. Kesulitan tersebut dibuktikan dari nilai rata-rata materi kelarutan dan hasil kali kelarutan kelas XI MIPA tahun pelajaran 2015/2016 yang lebih rendah dibanding nilai materi lain. Dari tujuh kelas, lima kelas memiliki nilai rata-rata harian terendah pada materi kelarutan dan hasil kali kelarutan. Materi ini menekankan pada keterampilan siswa untuk menguasai dan mengaplikasikan konsep ke dalam persoalan yang lebih kompleks. Banyak siswa yang merasa kesulitan dalam mempelajari materi ini dikarenakan selain siswa dituntut untuk menguasai konsep, siswa juga harus mampu menyelesaikan soal secara matema-tika. Suatu model pembelajaran yang sesuai diperlukan agar tujuan pembelajaran dapat tercapai maksimal dan membuat siswa lebih aktif dalam kegiatan belajar-mengajar.

Model pembelajaran yang tepat dan menarik akan membuat siswa lebih tertarik untuk mempelajari materi kimia khususnya materi kelarutan dan hasil kali kelarutan dan meningkatkan pemahaman terhadap materi. Model pembelajaran inkuiri terbimbing dan siklus belajar $5 \mathrm{E}$ (SB 5E) merupakan model yang dianggap sesuai untuk materi kelarutan dan hasil kali kelarutan pada kurikulum 2013. Kedua model ini menekankan pembelajaran berpusat pada siswa sehingga lebih banyak melibatkan siswa dalam pembelajaran dan membuat siswa membangun pengetahuan sendiri.

Berdasarkan kebebasan yang diberikan kepada siswa, inkuiri menurut National Research Council (NRC) dibedakan menjadi inkuiri terstruktur, terbimbing dan bebas. Perbedaan inkuiri terbimbing dengan inkuiri lain terletak pada peran guru dalam kegiatan pembelajaran, yaitu guru menyediakan masalah dan prosedur, yang nantinya siswa menentukan proses yang diikuti dan hasil yang akan dicapai [3]. Inkuiri terbimbing terbukti lebih efektif diterapkan daripada inkuiri bebas dan penerapannya dapat menghindari adanya miskonsepsi [4]. Penerapan model ini juga cocok 
dengan karakteristik siswa di SMA N 1 Boyolali yang belum terbiasa menggunakan pembelajaran inkuiri bebas sehingga masih memerlukan bimbingan agar arah dan tujuan pembelajaran dapat terpenuhi. Penggunaan inkuiri terbimbing akan menghemat waktu dan mengurangi ketakutan siswa terhadap ketidakpastian hasil penyelidikan. Siswa dalam pembelajaran akan diajak menemukan konsep sendiri dan diberi keleluasaan dalam berpikir dan aktif di kelas sehingga siswa mudah mengabstraksikan konsep tersebut ke dalam pikiran [5]. Pembelajaran inkuiri terbimbing juga menekankan proses pembelajaran berdasarkan langkah-langkah ilmiah yang dimasukkan ke dalam sintaks pembelajaran. Sintaks inkuiri terbimbing terdiri dari orientasi, merumuskan masalah, merumuskan hipotesis, mengumpulkan data, menguji hipotesis dan menarik kesimpulan [6]. Sintaks ini menyebabkan konsep pada materi kimia yang diajarkan terbentuk dengan baik dan lebih dipahami [7].

Model pembelajaran lain yang digunakan peneliti adalah model siklus belajar (SB 5E). SB 5E akan membuat siswa aktif mengkonstruksi konsep melalui sintaks yang terdiri dari lima fase yaitu engagement, exploration, explanation, elaboration dan evaluation [8]. Fase-fase dalam model ini selalu melibatkan siswa secara aktif di dalamnya. Pembelajaran yang meng-gunakan SB 5E dapat meningkatkan kemampuan ilmiah siswa, termasuk tingkat pemahaman dan pengetahuan. Persepsi siswa terhadap kegiatan belajar juga tampak positif [9] dan keaktifan meningkat [10]. Penerapan model ini juga meningkatkan minat dan rasa ingin tahu siswa diakibatkan siswa belajar secara bermakna dengan bekerja dan berpikir berdasarkan pengalaman lalu menggunakan pemahamannya ke suatu permasalahan lain [11]. Model SB $5 \mathrm{E}$ dilihat dari karakteristiknya sejalan dengan tuntutan kurikulum 2013 yang menginginkan pembelajaran yang berbasis sainstifik dan berpusat pada siswa.

Faktor lain yang dapat mempengaruhi hasil belajar kimia, khususnya materi kelarutan dan hasil kali kelarutan adalah kemampuan matematika. Hal ini karena materi kelarutan dan hasil kali kelarutan merupakan materi yang banyak mengaplikasikan konsep ke perhitungan matematis untuk menyelesaikan masalah yang berkaitan sehingga perlu adanya kemampuan matematika. Tingkat kemampuan matematika siswa mempengaruhi hasil belajar pada pembelajaran sains dimana siswa yang memiliki kemampuan matematika tinggi akan sukses dalam pembelajaran sains [12]. Kemampuan matematika akan mendukung siswa menyelesaikan masalah yang berkaitan dengan materi kelarutan dan hasil kali kelarutan yang sebagian bersifat hitungan.

Berdasarkan uraian yang dipaparkan sebelumnya, maka peneliti menilai perlu dilakukan penelitian mengenai perbandingan kedua model pembelajaran pada materi kelarutan dan hasil kali kelarutan dengan judul "Studi Komparasi Model Pembelajaran Inkuiri Terbimbing dan Sikus Belajar 5E Ditinjau dari Kemampuan Matematika terhadap Hasil Belajar Siswa pada Materi Kelarutan dan Hasil Kali Kelarutan Kelas XI SMA Negeri 1 Boyolali Tahun Pelajaran 2016/2017".

\section{METODE PENELITIAN}

Penelitian ini dilakukan di kelas XI MIPA SMA Negeri 1 Boyolali pada tahun pelajaran 2016/2017 semester genap. Metode penelitian yang digunakan adalah metode eksperimen dengan desain faktorial 2x2 [13] seperti pada Tabel 1.

Tabel 1. Desain Faktorial $2 \times 2$

\begin{tabular}{lcc}
\hline \multirow{2}{*}{$\begin{array}{l}\text { Model } \\
\text { Pembelajaran (A) }\end{array}$} & \multicolumn{2}{c}{$\begin{array}{c}\text { Kemampuan } \\
\text { Matematika }\end{array}$} \\
\cline { 2 - 3 } & $\begin{array}{c}\text { Tinggi } \\
\left(\mathrm{B}_{1}\right)\end{array}$ & $\begin{array}{c}\text { Rendah } \\
\left(\mathrm{B}_{2}\right)\end{array}$ \\
\hline Inkuiri Terbimbing & $\mathrm{A}_{1} \mathrm{~B}_{1}$ & $\mathrm{~A}_{1} \mathrm{~B}_{2}$ \\
$\left(\mathrm{~A}_{1}\right)$ & $\mathrm{A}_{2} \mathrm{~B}_{1}$ & $\mathrm{~A}_{2} \mathrm{~B}_{2}$ \\
SB 5E $\left(\mathrm{A}_{2}\right)$ & \\
\hline
\end{tabular}

Keterangan: $\quad A_{1} B_{1}=$ Pembelajaran menggunakan model inkuiri terbimbing pada siswa dengan kemampuan matematika tinggi, $A_{1} B_{2}=$ Pembelajaran menggunakan model inkuiri terbimbing pada siswa dengan 
kemampuan matematika rendah, $\mathrm{A}_{2} \mathrm{~B}_{1}=$ Pembelajaran menggunakan model SB 5E pada siswa dengan kemampuan matematika tinggi, $\mathrm{A}_{2} \mathrm{~B}_{2}=$ Pembelajaran menggunakan model SB 5E pada siswa dengan kemampuan matematika rendah.

Populasi dalam penelitian ini adalah siswa kelas XI SMA Negeri 1 Boyolali tahun pelajaran 2016/2017. Pengambilan sampel menggunakan teknik cluster random sampling [14] dan mendapatkan dua sampel sebagai kelas eksperimen. Kelas XI MIPA 7 sebagai kelas eksperimen I diberi model inkuiri terbimbing, sedangkan kelas XI MIPA 5 sebagai kelas eksperimen II diberi model SB 5E. Kedua kelas diuji terlebih dahulu dengan uji t-matching, normalitas dan homogenitas sebagai prasyarat analisis [13].

Variabel terikat dalam penelitian ini adalah hasil belajar siswa pada materi kelarutan dan hasil kali kelarutan (aspek pengetahuan, sikap dan keterampilan). Variabel bebasnya meliputi model inkuiri terbimbing dan SB 5E, sedangkan variabel moderator penelitian ini adalah kemampuan matematika. Pengambilan data dilakukan dengan menggunakan metode tes untuk mengukur aspek pengetahuan dan kemampuan matematika, metode angket untuk aspek sikap serta metode observasi untuk aspek sikap dan keterampilan.

Instrumen dalam penelitian ini meliputi silabus, Rencana Pelaksanaan Pembelajaran (RPP), soal tes pengetahuan, soal tes kemampuan matematika, angket sikap serta lembar observasi sikap dan keterampilan.

Formula Gregory digunakan untuk menguji validitas isi instrumen penelitian [14] dan didapatkan bahwa semua instrumen dinyatakan valid dengan nilai Content Validity $(\mathrm{CV})>0.700$. Instrumen pengetahuan dan kemampuan matematika diuji reabilitas dengan rumus Kuder Richardson $\left(\mathrm{KR}_{20}\right)$ [14]. Harga reabilitas instrumen pengetahuan dan kemampuan matematika berturut-turut yaitu 0,866 dan 0,801 sehingga dinyatakan reliable dan dapat digunakan karena lebih besar dari kiteria minimum $(0,700)$. Angket aspek sikap diuji reabilitas dengan menggunakan rumus alpha [14] dengan hasil instrumen dinyatakan reliable dan $\alpha$ $=0,813$. Uji tingkat kesukaran dan daya pembeda juga dillakukan pada instrumen pengetahuan. Instrumen pengetahuan yang digunakan sudah memenuhi semua kriteria.

Teknik analisis data yang digunakan adalah uji analisis variansi dua jalan untuk aspek pengetahuan dan keterampilan yang berupa data normal dan homogen. Aspek sikap diuji dengan uji statistik non parametrik Kruskal Wallis $H$ karena tidak berdistribusi normal [13]. Kedua analisis dilakukan dengan bantuan software SPSS 20.

Prosedur penelitian dilakukan dalam beberapa tahap, yaitu: (1) observasi pembelajaran kimia, (2) penentuan sampel penelitian, (3) uji coba instrumen, (4) pemberian tes kemampuan matematika pada siswa kelas eksperimen, (5) pelaksanaan pembelajaran dengan model yang ditentukan di masing-masing kelas, (6) pemberian tes pengetahuan, (7) pengolahan dan analisi data dan (8) penarikan kesimpulan.

\section{HASIL DAN PEMBAHASAN}

Kondisi awal kedua kelas eksperimen diuji untuk mengetahui kesetaraan kedua kelas, normalitas sampel dan homogenitas sampel. Data kondisi awal yang digunakan berupa nilai ulangan akhir semester ganjil siswa. Berdasarkan uji kesetaraan dengan $t$ matching diperoleh signifikansi sebesar 0,690 , lebih besar dari a $(0,050)$ sehingga dapat disimpulkan bahwa kedua kelas setara. Kedua kelas eksperimen juga berasal dari populasi berdistribusi normal dilihat dari hasil uji normalitas yang lebih besar dari nilai $\alpha$. Signifikansi untuk kelas XI MIPA 5 dan XI MIPA 7 berturut-turut yaitu 0,440 dan 0,077 . Hasil uji homogenitas terhadap keduanya menunjukkan bahwa kedua kelas homogen dengan nilai signifikansi sebesar 0,139, lebih besar dari $\alpha$.

Perbandingan distribusi frekuensi nilai aspek pengetahuan, sikap dan keterampilan dari kedua kelas dapat dilihat pada Gambar 1, 2 dan 3. . 


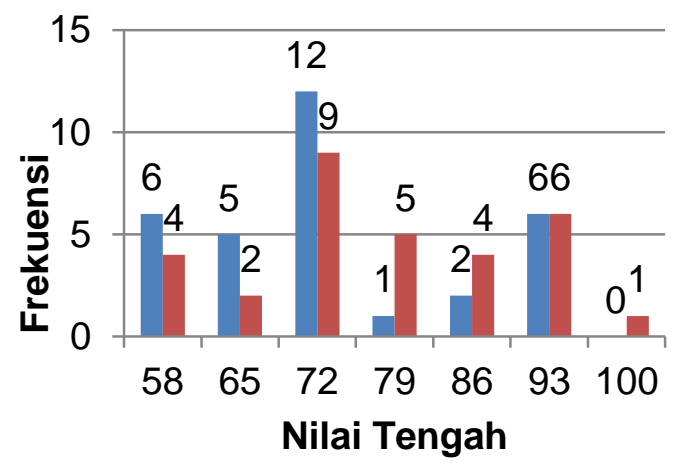

- Kelas Inkuiri Terbimbing

- Kelas SB 5E

Gambar 1. Histogram Nilai Pengetahuan Siswa

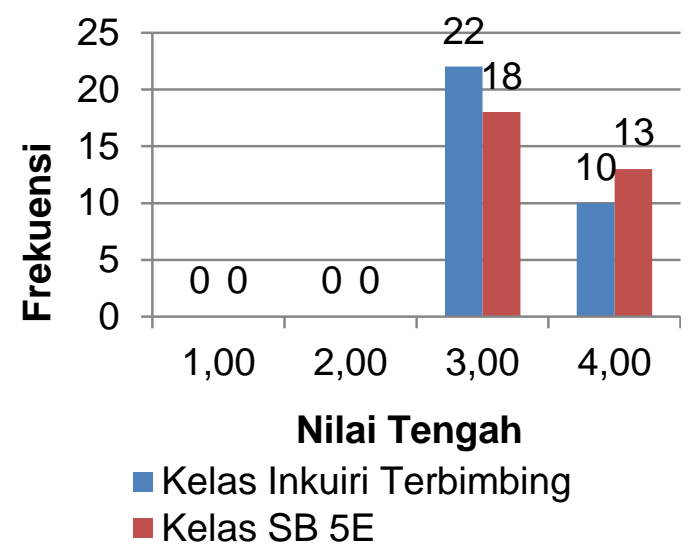

Gambar 2. Histogram Nilai Sikap Siswa

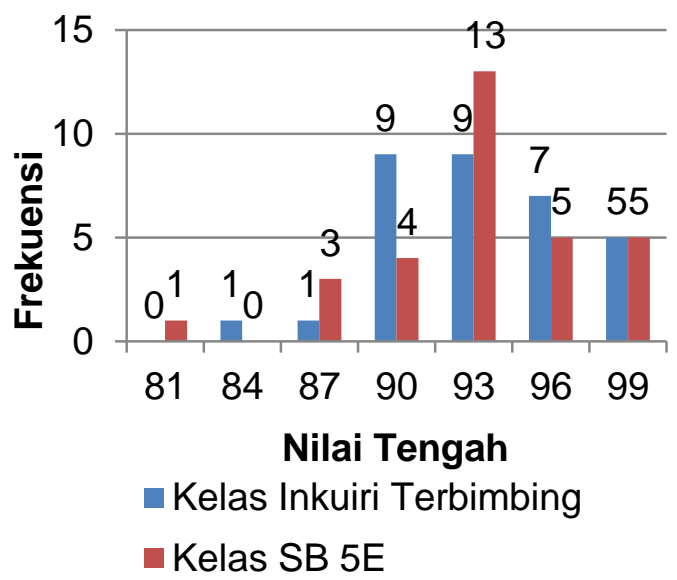

Gambar 3. Histogram Nilai Aspek Keterampilan

Hasil uji hipotesis dengan menggunakan analisis variansi dua jalan untuk aspek pengetahuan disajikan pada Tabel 2 dan untuk aspek keterampilan pada Tabel 3. Hasil uji statistik non parametrik Kruskal Wallis untuk uji hipotesis aspek sikap disajikan pada Tabel 4.

Hipotesis dalam uji analisis variansi diterima saat nilai signifikansi yang diperoleh lebih besar dari nilai a dan begitu pula pada uji Kruskal Wallis. Uji hipotesis pertama mengenai pengaruh model pembelajaran inkuiri terbimbing dan SB 5E terhadap hasil belajar pada Tabel 2, 3 dan 4 dapat dilihat bahwa pada aspek sikap dan keterampilan $\mathrm{H}_{0}$ diterima, namun pada aspek pengetahuan tidak. Hal ini menunjukkan bahwa model pembelajaran inkuiri terbimbing dan SB 5E memberikan pengaruh terhadap hasil belajar aspek pengetahuan, tetapi tidak terhadap aspek sikap maupun keterampilan.

Tabel 2. Hasil Uji Analisis Variansi Hasil Belajar Pengetahuan

\begin{tabular}{lcc}
\hline \multicolumn{1}{c}{ Sumber } & $\begin{array}{c}\text { Signifikansi } \\
\text { (Sig.) }\end{array}$ & $\alpha$ \\
\hline $\begin{array}{l}\text { Model } \\
\text { Pembelajaran (A) }\end{array}$ & 0,013 & 0,050 \\
$\begin{array}{l}\text { Kemampuan } \\
\text { Matematika (B) }\end{array}$ & 0,025 & 0,050 \\
Interaksi (AB) & 0,981 & 0,050 \\
\hline
\end{tabular}

Tabel 3. Hasil Uji Analisis Variansi Hasil Belajar Keterampilan

\begin{tabular}{lcc}
\hline \multicolumn{1}{c}{ Sumber } & $\begin{array}{c}\text { Signifikansi } \\
\text { (Sig.) }\end{array}$ & $\mathrm{A}$ \\
\hline Model & 0,835 & 0,050 \\
$\begin{array}{l}\text { Pembelajaran (A) } \\
\text { Kemampuan }\end{array}$ & 0,893 & 0,050 \\
$\begin{array}{l}\text { Matematika (B) } \\
\text { Interaksi (AB) }\end{array}$ & 0,397 & 0,050 \\
\hline
\end{tabular}

Tabel 4. Hasil Uji Kruskal Wallis Hasil Belajar Sikap

\begin{tabular}{lcc}
\hline \multicolumn{1}{c}{ Sumber } & $\begin{array}{c}\text { Asymp. } \\
\text { Sig. }\end{array}$ & $\mathrm{A}$ \\
\hline $\begin{array}{l}\text { Model Pembelajaran } \\
\text { (A) }\end{array}$ & 0,382 & 0,050 \\
$\begin{array}{l}\text { Kemampuan } \\
\text { Matematika (B) }\end{array}$ & 0,760 & 0,050 \\
Interaksi (AB) & 0,647 & 0,050 \\
\hline
\end{tabular}

Model SB 5E yang disusun sedemikian rupa sehingga siswa mengalami proses pembelajaran secara 
bertahap dan runtut dari fase engagement sampai evaluation. Siswa pada tahap engagement dibangkitkan perhatian dan minat terhadap konsep yang akan dipelajari dengan mengkaitkan dengan pengalaman siswa, sehingga muncul ketertarikan terhadap materi. Setelah muncul minat, siswa akan diberi kesempatan menggali konsep dan memecahkan permasalahan dalam fase exploration, lalu siswa menjelaskan dan mendiskusikan hasil ekplorasi yang diperoleh pada tahap explanation. Tahap berikutnya siswa mengaplikasi-kan konsep yang didapat dalam situasi baru tetapi masih berhubungan dalam tahap elaboration. Tahap terakhir yaitu evaluation, siswa menguji hasil belajar dan mengevaluasi proses belajar yang dilakukan [8]. Siswa mempelajari materi secara bermakna dengan mengkontruksi pengetahuan melalui tahapan tersebut.

Akibat siswa belajar secara bermakna dengan bekerja berdasarkan pengalaman lalu menggunakan pemahamannya ke suatu permasala-han lain, peningkatan minat dan rasa ingin tahu terjadi [11]. Model pembelajaran SB 5E memiliki fase elaboration membuat siswa akrab dengan konsep yang digunakan dan bisa berasimilasi atau menampung konsep baru ke dalam pikiran siswa [15]. Kelebihan ini yang menyebabkan model pembelajaran SB 5E memberikan pengaruh terhadap hasil belajar aspek pengetahuan pada materi kelarutan dan hasil kali kelarutan.

Model inkuiri terbimbing yang diterapkan di kelas lain juga mengedepankan pembelajaran penemuan konsep dan membuat siswa aktif, namun tetap terarah dengan bimbingan guru. Model ini membantu siswa mempelajari materi ilmiah, menguasai kemampuan ilmiah dan memahami sifat ilmu alam lalu ditambah lagi model ini mencegah terbuangnya waktu, mengurangi frustasi siswa karena eksperimen gagal dan mengurangi ketakutan siswa terhadap ketidakpastian [3]. Materi kimia termasuk ilmu alam dan bersifat ilmiah menyebabkan inkuiri terbimbing sesuai untuk mempelajari materi kimia. Adanya bimbingan guru dalam proses pembelajaran inkuiri terbimbing menyebabkan siswa tidak mengalami miskonsepsi dan pem-belajaran terarah, sehingga siswa memahami konsep pada materi lebih baik.

Pembelajaran dengan model ini juga menekankan proses pembelajaran berdasarkan langkah-langkah ilmiah. Proses pembelajaran dimulai dengan langkah orientasi untuk mengenalkan dan mengajak siswa berpikir memecah-kan masalah. Kemudian siswa merumuskan masalah dari orientasi yang didapat terkait materi yang dipelajari, lalu merumuskan hipotesis sebagai jawaban rumusan masalah. Siswa akan menyelidiki dan mengumpulkan data yang dibutuhkan, kemudian siswa meng-gunakan data tersebut untuk menguji hipotesis. Langkah terakhir, siswa menyimpulkan hasil temuan yang diperoleh. Langkah-langkah pembelajaran ini akan membuat konsep pada materi kimia yang diajarkan terbentuk dengan baik dan lebih dipahami [7].

Berdasarkan uraian di atas, maka model pembelajaran SB 5E dan inkuiri terbimbing sangat baik diterapkan pada materi kimia yang menerapkan konsep ke dalam hitungan seperti materi kelarutan dan hasil kali kelarutan pada siswa kelas XI SMA Negeri 1 Boyolali karena memberikan pengaruh terhadap hasil belajar aspek pengetahuan. Kedua model pembelajaran ini sama-sama membuat siswa lebih memahami konsep materi kelarutan dan hasil kali kelarutan, sehingga membuat siswa dapat mengaplikasikan konsep tersebut untuk mengerjakan tes aspek pengetahuan.

Perihal mengenai tidak ada pengaruh model pembelajaran terhadap aspek sikap maupun keterampilan disebabkan karena pemilihan model pembelajaran didasarkan pada karakteristik bahan ajar dan siswa sehingga tidak secara langsung mempengaruhi hasil belajar sikap dan keterampilan. Peningkatan sikap dalam pembelajaran kimia di kurikulum 2013 hanya sebagai kegiatan yang memiliki dampak pengiring.

Hipotesis selanjutnya mengenai pengaruh kemampuan matematika terhadap hasil belajar pada Tabel 2, 3 dan 4 mennunjukkan hasil yang sama. 
Hipotesis untuk aspek sikap dan keterampilan diterima, sedangkan untuk aspek pengetahuan tidak. Kemampuan matematika pada dasarnya sebuah kemampuan pada seseorang yang berasal dari logika atau pemikiran sehingga akan memberikan pengaruh pada hasil belajar yang memerlukan pemikiran seperti pengetahuan yang mengukur pemahaman konsep terhadap materi.

Tes pengetahuan pada dasarnya dilakukan untuk mengetahui seberapa banyak informasi mengenai konsepkonsep yang ada dalam materi telah mereka pahami. Perbedaan kemampuan matematika dapat menyebabkan perbedaan kemampuan siswa dalam memahami konsep karena materi kelarutan dan hasil kali kelarutan memiliki banyak materi hitungan. Hal ini yang memungkinkan siswa dengan kemampuan matematika tinggi mudah dalam mempelajari materi kelarutan dan hasil kali kelarutan, sehingga akan lebih mudah menjawab soal tes pengetahuan dibanding siswa yang memiliki kemampuan matematika rendah. Merdekawati (2013) menyatakan siswa berkemampuan matematika tinggi akan dengan mudah menyelesaikan soal yang bersifat hitungan dikarenakan siswa dapat menghubungkan permasalahan dalam kimia dengan konsep hitungan yang sudah ada dalam struktur kognitif siswa [16]. Kemampuan matematika menjadi kunci utama dalam menyelesaikan soal pada materi kelarutan dan hasil kali kelarutan yang bersifat hitungan.

Tidak ada pengaruh kemampuan matematika terhadap hasil belajar aspek sikap maupun keterampilan disebabkan indikator dalam kemampuan matematika tidak terwakili dalam penilaian keduanya. Penilaian sikap dalam kurikulum 2013 menilai sikap sosial dan spiritual, sedangkan penilaian keterampilan dalam penelitian sebatas pada keterampilan praktikum dan menyusun laporan.

Uji hipotesis terakhir untuk menguji interaksi model pembelajaran dan kemampuan matematika pada Tabel 2, 3 dan 4 menunjukkan tidak ada interaksi antara model pembelajaran dengan kemampuan matematika terhadap hasil belajar baik aspek pengetahuan, sikap maupun keterampilan. Tidak ada interaksi antara keduanya menunjukkan bahwa siswa dengan kemampuan matematika tinggi akan memperoleh hasil yang lebih tinggi dari siswa dengan kemampuan matematika rendah apapun model pembelajaran yang digunakan.

\section{KESIMPULAN}

Kesimpulan yang didapatkan berdasarkan hasil penelitian yang telah dilakukan yaitu: (1) terdapat pengaruh model pembelajaran inkuiri terbimbing dan SB 5E terhadap hasil belajar aspek pengetahuan, namun tidak terhadap aspek sikap dan keterampilan; (2) terdapat pengaruh kemampuan matematika terhadap hasil belajar aspek pengetahuan, namun tidak terhadap aspek sikap dan keterampilan; (3) tidak ada interaksi antara model pembelajaran dengan kemampuan matematika terhadap hasil belajar.

\section{UCAPAN TERIMA KASIH}

Penelitian ini dapat terselesaikan dengan baik atas bantuan dari bebagai pihak. Penulis mengucapkan terima kasih kepada Drs. Agung Wardoyo selaku kepala SMA Negeri 1 Boyolali atas izin untuk melaksanakan penelitian, Dra. Endang Jatiningsih selaku guru kimia SMA Negeri 1 Boyolali yang telah memberikan waktu mengajar pada penulis untuk melakukan penelitian, serta siswa kelas XI MIPA 5 dan 7 SMA $\mathrm{N} 1$ Boyolali yang telah bekerja sama melancarkan penelitian.

\section{DAFTAR RUJUKAN}

[1] Organisation for Economic Cooperation and Development. 2016. PISA 2015 PISA Results in Focus. Paris: OECD.

[2] Suyono dan Hariyanto. 2014. Belajar dan Pembelajaran. Bandung: Remaja Rosdakarya. 
[3] Zion, M., \& Mendelovici, R. 2012. Science Education International, 23(4), 383-399.

[4] Kirschner, P. A., Sweller, J., \& Clark, R. E. 2006. Educational Psychologist, 41(2), 75-86.

[5] Murningsih, I.M.T., Masykuri, M., \& Mulyani, B. 2016. Jurnal Inovasi Pendidikan IPA, 2(2), 177-189.

[6] Majid, Abdul. 2013. Strategi Pembelajaran. Bandung: Remaja Rosdakarya.

[7] Kurniawati, D., Masykuri, M., \& Saputro, S. 2016. Jurnal Pendidikan Kimia (JPK), 5(1), 8895.

[8] Bybee, R. W., Taylor, J. A., Gardner, A., Van Scotter, P., Powell, J. C., Westbrook, A., \& Landes, N.. 2006. The BSCS 5E instructional Model: Origins and Effectiveness. Colorado Springs, Co: BSCS.

[9] Liu, T. C., Peng, H., Wu, W. H., \& Lin, M. S. 2009. Educational Technology \& Society, 12(4), 344358.
[10] Rahayuningsih, R., Masykuri, M., \& Utami, B. 2012. Jurnal Pendidikan Kimia (JPK), 1(1), 51-58.

[11] Utami, B., Hastuti, B., Yamtinah, S., Padmini, S., \& Arroyan, F. 2013. Jurnal Cakrawala Pendidikan, 32(2), 315-325.

[12] Oyedeji. 2011. World J Young Researchers, 1(4), 61-65.

[13] Budiyono. 2009. Statistika untuk Penelitian. Surakarta: UNS Press.

[14] Basuki, Ismet dan Hariyanto. 2014. Asesmen Pembelajaran. Bandung: Rosdakarya.

[15] Madu, B. C., \& Amaechi, C. C. 2012. Journal of Education and Practice, 3(9), 173-181.

[16] Merdekawati. Krisna. 2013. Jurnal Inovasi dan Kewirausahaan, 2(1), 26-31. 